\title{
Smit, Johannes
}

North-West University

Potchefstroom Campus

School for Ecclesiastical studies

\section{The Reformed Churches in South Africa \\ - a perspective on church's view of the state}

\begin{abstract}
In this paper it is argued that the Reformed Churches in South Africa has a positive view of state government in the light of the Belgic Confession article 36 and Church Order Article 29. However, the separation of church and state should be maintained because church and state have different callings in society. Preferably church and state should be able to work together regarding issues of mutual interest. The precondition is that the separation of church and state may not be compromised. For the churches it is about freedom in the state, to exercise their mandate according sound Scriptural conduct. It means the exercise of church's mandate without compromising the basic principles of justice and equity. Just is just in church and state, but the way it is exercised may differ in church and state because of the difference in foundation, nature and focus.
\end{abstract}

\section{Contextualization}

What are the Reformed Churches in South Africa's (RCSA) view of the state? Embedded in South African history of the last hundred and fifty years it may be possible to analyse the RCSA's attitude towards some of the great social political questions of the last century and a half. Some issues that may be tabled are for example the RCSA's attitude towards the development of Afrikaner nationalism after the Anglo Boer War at the start of the 20th century, the up building of the country after the war, the question of white poverty in the previous century and in contemporary society, the churches view of Apartheid etc. However, the limit on time and space makes it impossible to address all these issues. I purposefully contain myself in context of this conference to aspects which determine the Reformed Churches in South Africa's view of the state. First, the focus is on an aspect that is generally overlooked by historiography outside the RCSA, namely the quest for freedom by the founding fathers of the RCSA. Second, the focus is on the interpretation of article 36 by the RCSA. Third, a few remarks are made about the practical embodiment of the RCSA's view of the state in terms of article 28 of the church order.

\section{A "FREE" CHURCH}

\subsection{Founding of the Reformed Churches in South Africa}

The Reformed Churches in South Africa came into being on February 11, 1859. Historiography (outside the Reformed Churches) tends to view the founding of this church community as a result of the Nederduitsch Hervormde Kerk (NHK) acceptance of "Gesange" (free hymns) in public worship (Theon \& De Wit, 2010:154; Scholtz, 1956:149 e.v., 161). The "Gereformeerdes" were strongly opposed to the use of these hymns. The schism however was the result of other 
frustrations and the use of the hymns in public worship the culmination thereof. In summary the main reasons for the schism were the influence of theological liberalism of the church in the Netherlands, inadequate preaching of the gospel, secular education, and state control of the church (cf. Giliomee, 2003:178). The latter is of importance for this article. On January 12,1859 , fifteen of the "Gereformeerdes" wrote a letter to the "Algemene Kerkvergadering" (General Assembly) of the NHK to declare that they want to exist as a "Free Reformed Church" (Vrije Gereformeerde Kerk) according to the doctrine, discipline and liturgy accepted by the Synod of Dordrecht 1618/19 (Spoelstra, 1915:197). In that context at least two different levels of application can be ascribe to the word "free".

- "Free" indicates a rejection of the state-church model endorsed by the constitution of the Zuid-Afrikaansche Republik. The objection was not only against the fact that ministers were remunerated by the state, but inter alia against the practice to ask the "Volksraad" to adjudicate cases with a distinct internal church nature. The state church (the NHK) also became in time more dependent of support by the state. For the Gereformeerdes it was unacceptable for the church to transfer the responsibility of church government to the state as if Christ did not give an order for the church that should be maintained by the church.

- "Free" also indicates a way of church governance free of internal hierarchical structure and freedom of conscience. The first minister of the reformed churches in South Africa, rev. Dirk Postma, noted in his diary that God calls him to position himself against the principle of hierarchy (Dagboek van Dirk Postma, 10 Jaunuarie, 1859). The background of this remark is the rejection of Postma's suggestion by the general assembly of the NHK that the singing of free hymns should be left to the conscience of every minister serving in a local church.

Instead, the general meeting of the in NHK decided that the free hymns together with the Psalms should be sung in public worship. The "Gereformeerdes" viewed this decision as a binding of the conscience and a yoke of human ordinances on the believers (Spoelstra, 1963:197 e.v.; Jooste, 1958:55).

\subsection{Difference between church and state government}

According the Gereformeerdes it did not matter how positive the state's attitude towards the church may be, it is imperative that the church should function independent of the state. At a personal meeting Postma explained to reverend Van der Hoff, minister of the NHK, that the church is a religious body that should not be dependent on the state for its functioning and for the development of both church and state. The point of difference between the church and the state, according to Postma, is that the kingdom of God is pneumatological determined and not by civil authority (Dagboek van Dirk Postma, 24 Januarie, 1859). The principal distinction made is that church government should clearly be distinguished from civil government on the basis that church government is not of the same nature. The focus of church government is on the spiritual dimension, while the state is responsible for governance of the mundane.

However, it became clear that it was incomprehensible for the leadership of the state government (in context of the state church) and the NHK to accept that the majority (in favour of the singing of the free hymns) should account for the opinion of the minority. This position of the latter increased the tension between those in favour of the singing of free hymns and those against it. The Gereformeerdes viewed the majority opinion as the incorporation of a 
democratic principle in church government. As such the so-called liberal or democratic ideas of state government, well accepted by the Gereformeerdes in context of state government was rejected as normative for the government of the church (Spoelstra, 1963:140-141). For the Gereformeerdes the separation of church and state was imperative; it was about the true freedom of the church and how the state should act with regard to public worship.

\subsection{Obedience to state government}

The RCSA's emphasis on the separation of church and state did not translate into an antagonistic view of the state. The state is instituted by God. All believers should acknowledge the state as such and should be obedient to the state without compromising their belief. This point of view is directly linked to article 36 of the Belgic confession. The Belgic Confession states:

Moreover everyone, regardless of status, condition, or rank, must be subject to the government, and pay taxes, and hold its representatives in honour and respect, and obey them in all things that are not in conflict with God's Word, praying for them that the Lord may be willing to lead them in all their ways and

that we may live a peaceful and quiet life in all piety and decency.

John Calvin's commentary on Daniel 6:22 gives a perspective on how to understand the phrase ... [to] obey them in all things that are not in conflict with God's Word ... When king Darius came to Daniel while he was still in the lion's den, Daniel said to the King:

My God hath sent his angel, and hath shut the lions' mouths, that they have not hurt me: forasmuch as before him innocency (sic) was found in me; and also before thee, $\mathrm{O}$ king, have I done no hurt.

According to Calvin Daniel did not transgress against the king by constantly persevering in the exercise of piety. The fear of God ought to precede, that kings may obtain the authority. The rational of the argument is that when God is feared in the first place earthly princes will obtain their authority. The Christian is therefore compelled to obey the command of God and should neglect what the government may order in opposition to it. Calvin concludes that earthly princes lay aside all their power when they rise up against God (Calvin, 6:22).

From Calvin's exposition it is clear that when a state government acts against Christians or against their belief it is a violation of the office bestowed upon them by God. It is true that some things belong to the Caesar, but it is also true that some things belong to God. In fact, everything belongs to God. The kingdom of God includes everything on earth and therefore also the kingdom of a Caesar. God governs in Christ over the entire cosmos (Van Wyk, 1991:111). Therefore the state may not govern over the church and the church not over the state. Both are subject to the kingdom of God. Both have a unique calling and mandate and both is in its own way and independent of the other focused on the kingdom of Jesus Christ (Du Plooy, 2008:244-245). If it happens that Caesar makes a claim on that which belongs to God it is the responsibility of the Christian to be more obedient to God than to the Caesar. It is not a choice between obedience to God and obedience to the Caesar, but obedience to God through the Caesar; the attitude of David towards Saul not to attack the king (Saul) because he was anointed by God (1 Sam. 24:7; Van Wyk, 1991:111). 


\section{DOCTRINAL DEVELOPMENTS}

\subsection{Problem posed by the Belgic Confession article 36}

The main problem posed by article 36 of the Belgic confession, namely how the mandate of the state should be interpreted was in the first years after the Reformed Churches in South Africa came into being not viewed as problematic. Muller (2010:117-157) indicated that the Reformed Churches in South Africa until 1982 interpreted article 36 of the Belgic confession in the way that the state government should actively remove and destroy idolatry and false worship of the Antichrist. This interpretation of article 36 is in line with scholars like Polman, Vischer and others who accept that it was the intention of De Brés to ascribe such authority to state government. Accordingly state government was viewed to execute a twofold office. State government has to restrain civilians from dissoluteness and in the second place should actively remove and destroy idolatry and false worship of the Antichrist. This interpretation of article 36 is mainly based on the view that Calvin and his followers were in favour of a theocratic form of state government (cf. Coetzee, 2006:143-157).

The question is if it was the intention of De Brés, main author of the Belgic confession, that state government should actively remove and destroy idolatry and the false worship of the Antichrist, featured in the Reformed Churches in South Africa for the first time at the Synod of 1910.

\subsection{RCSA synod decisions}

In 1910 the Reformed Church Steynsburg asked the Synod to amend article 36 in the same way as the reformed churches in the Netherlands in 1905. The Synod decided, however, that it was not necessary to attend to the matter. For approximately 70 years the formulation and interpretation of article 36 featured at different Synods of the Reformed Churches in South Africa. In 1982 Synod made a small but significant change in the formulation of article 36. The Synod decided to include the Afrikaans word "sodoende" in paragraph 3. This inclusion was accepted as a better translation of the original text of article 36. However, the use of this word did not only give a better translation, but also a significant change to the meaning of article 36 .

\subsection{Interpretation of the Belgic Confession article 36}

This change entails that some aspects of article 36 that were previously viewed as part of the mandate of state government is now part of the purpose of state government. Article 36 , for example, does not state in the new formulation that the state government has the responsibility to actively remove and destroy idolatry and false worship of the Antichrist, but to carry out its mandate in such a way that in this process idolatry and false worship of the Antichrist would be destroyed. The significance of this change is that the new formulation is directly or indirectly based on the acknowledgement that De Brés did not intend to ascribe the responsibility to the state government to act against idolatry or false worship of the Antichrist. It is the task of state government to govern in such a way that it is possible for the church to destroy idolatry and false worship of the Antichrist by the proclamation of the gospel. It seems that the new formulation is not only a better translation of the passage, but also provide for a better understanding of the purpose of the original formulation. It also gives a better reflection of Scriptures revelation on the mandate and purpose of state government (Muller, 2010: $155 \mathrm{ff}$. ). 


\subsection{View of the state}

What then are the origin, mandate and purpose of state government viewed from a reformed perspective in context of the Reformed Churches in South Africa? I want to emphasize, however not extensively, some important aspects in context of article 36 of the Belgic confession.

First, the kingdom of God includes all forms of authority and governance; the differences in the government of different institutions, like church and state cannot be viewed in terms of article 36 of the Belgic as a dualism. Reality cannot be separated in different spheres of government. God's governance extends over the cosmos; it includes church and state and is directed against the power of Satan. Church and state government cannot be viewed in terms of a dualism, but should be described in terms of a duality. When the Bible speaks for example of the citizenship of the kingdom of God it does not situate the citizenship of the kingdom against worldly citizenship, but indicates in an eschatological way that believers are citizens of the perishing world and citizens of the new earth. The kingdom of God is a reality in this world as God's gracious gift for sinners. It starts to be realized where ever people submit in belief to the governance of Christ and live according his ordinances as the church. Again, the difference between church and state government is not found in a dualism, but therein that God does not govern everywhere in the same way. The consequence is that there is only one kingdom, but a lot of regiments. Therefore church and state is in service of the kingdom of God even if the state does not acknowledge the governance of God in Christ and their position as an institution of God (Van Wyk, 1991:234-235).

Second, the authority of state government does not evolve from government as such. No form of government is a purpose unto itself. All authority comes from God. From a reformed perspective the God does not transfer his authority to state government, but bestow authority on state government. It is a fundamental Scriptural principle that God does not transfer his of authority to a person, institute or to state government. Every authority bearer receives his authority from God and should in the final instance account for the exercise of its authority to God. It is therefore a question of how state government exercises authority in and towards the community. According to Van Wyk (1991:112) the responsibility of state government is not only to govern in an orderly way, but to account for its governance for justice and freedom. State government should govern in such a way that order, justice, freedom and responsibility become a feature of the community.

In a certain way church and state come close to each other in the execution of the separate mandates. Good state government and politics should realize something of the principles of the kingdom of God (cf. Van Wyk, 1991:112). They should act towards peace and reconciliation, freedom and justice. Realistically viewed there will be a difference in the nature and the way these principles realize in church and state. Spiritual salvation is after all not the same as political salvation. But the ethical demands of the kingdom of God should not be ignored by the state because it is also applicable to state government and politics.

\section{Third, article 36 states:}

"And the government's task is not limited to caring for and watching over the public domain but extends also to upholding the sacred ministry, with a view to removing and destroying all idolatry and false worship of the Antichrist; to promoting the kingdom of Jesus Christ; and to furthering the preaching of the gospel everywhere; to the end that God may be honoured and served by everyone, as he requires in his Word." 
In light of the controversy about article 36 it is important to notice that the mentioned four phrases are indicative of the purpose of state government and not a description of the mandate state government should execute. This is a clear limitation of the authority of state government. It is for example not the mandate of state government that the gospel is proclaimed, but that it can be proclaimed. The limitation of state authority in this way is supported by the principled view of the separation of church and state. State government does not have the calling or authority to interfere in the internal matters of a church community and the church should not interfere with state matters.

Reformed scholars from different disciplines describe the separation of church and state in terms of the philosophical doctrine of sovereignty in own circle. Van Wyk indicates that the idea of sovereignty may lead to confusion, because no area or sphere can be sovereign in its own circle. All areas and all authority are relative in light of the kingship of Jesus Christ. It is one of the problems with the Lutheran doctrine of the two kingdoms, and the division of reality in sovereign spheres that Eigengeständichkeit becomes all too soon Eigengesetzlichkeit. Regarding the different areas of governance it is a distinction between a difference in authority and function in the light of the one Word of God. Some scholars are of the opinion that article 36 of the Belgic confession is in favour of, in fact confesses a theocratic or even religious state model.

In my view it may be possible to deduce from the background, context and the text of article 36 the ideal of a state governed by Christians. But it is not possible to indicate from the text, also in relationship with article 37 that the confessions ascribe to a specific form of state government. It should be considered that article 36 developed in the context of the $16^{\text {th }}$ and 17th centuries church state relationships and that the views of Calvin are important background material for the understanding of article 36 . It was mentioned in this article that it is not possible to declare with certainty that Calvin was theocratic in his view of the state. What is certain is that article 36 states that the state and the authority bestowed upon the state as well as the authority of the church comes from God; that there are distinct differences, and that neither should claim authority over the other nor should they interfere with the execution of each other's mandates.

It should also be considered that it is not the purpose of the confessions to choose for a specific form of state government, may it be aristocratic, democratic etc. It is also possible that an autocracy governed with wisdom, compared with to a democracy that is governed badly may be able to give a better realization of Scripture values than the latter. Article 36 of the Belgic confession articulates the view (according to the new formulation) that state government irrespective of its acceptance of Christianity should allow the opportunity for the church to execute its mandate according Scriptures. Such an understanding of article 36 is in line with the New Testament revelation of the state. There is after all no indication in the New Testament that the church should establish a Christian state or that the existing state should be replaced by a Christian government. It may be a noble idea, but it is not part of article 36 of the Belgic confession.

\section{Practical embodiment}




\subsection{Confession and church order}

The first part of the first sentence of article 28 of the Church Order is a summary of what the churches confess about the state government in article 36 of the Belgic confession. It states:

"Precisely as civil authorities, as institutions of God, are obliged to assist and protect the church and its office bearers ..."

Most church order commentaries refer to Jansen (1952:130) who suggests that in the context of the Synod of Dordrecht 1618/19 article 28, was included to evoke a favourable attitude of the state towards the churches gathered in Synod. In that context (of a state church) it was important that the state government should confirm the church order. If the church order was confirmed by the state it would have the same authority as state legislation. Furthermore, it was mandatory for the Synod of Dordrecht $1618 / 19$ to give a clear outline of the responsibilities of both church and state. The purpose was to give a perspective on the position of the church in relationship to the state and state government.

The influential views of the day were that of the Armenians (and the Erastians) and Roman Catholicism. The Armenians were of the opinion that the state government functions over the church, while for the Roman Catholic Church the state government functions under the supervision of the church. The importance of this short piece of history is twofold. Because of the church state relations in the Netherlands the ideal of a church independent of the state could not be realized at the Synod of Dordrecht 1618/19. Of even more importance is that the church did not position itself against the state. According the reformed view church and state are not two separate entities that are positioned over and against each other. The church functions in the state and is in this sense subject to state governance.

This perspective of the reformers is a fundamental break with the mediaeval view of the relationship between church and state. In mediaeval times church and state were not formally separated. They functioned as a spiritual-juridical unity that could be distinguished but not separated from each other. The juridical discipline, the state and state government were all in service of the truth of God (Smit, 2009:476). Article 36 of the Belgic confession does not only represent a break with the mediaeval views on church and state, but in the light of the kingdom of God indicates the way for the church's view of the state and the conduct in the state.

A principle idea of article 28 of the Church Order of Dordt mentioned above, namely that the church does not function over and against the state but in the state, this is supported by the first duty ascribe to the church in article 28. However, the emphasis is not on the church, but on the "... duty of all ministers, elders and deacons to impress upon church members, faithfully and diligently, the need to obey and honour the government." This formulation is against a Congregationalist or hierarchical concept of church. The Congregationalist concept of the church in most instances demands that a matter regarding church and state would be referred to the governing body/executive of the church. But reformed church polity view the local church as a complete church.

Church unity is not experienced and exercised on the basis of structural unity, but is religious by nature based on the attributes of the church, namely unity, sanctity, catholicity and apostolicity (Du Plooy, 1982). This few remarks on church community are sufficient for the purposes of this article. The focus of the church order is in the first instance on the offices 
in the local church (congregation). In every local church the offices are responsible for the governance of the congregation. Their governance is a governance of service through the proclamation of the gospel (Smit, 1997, A governing of the heart. Mainly as seen by John Calvin). A concrete task of the offices is to call the congregation to obey and honour the state government. Church order commentaries are vague on why the emphasis is placed on the ministry of the offices. However, in context of article 36 of the Belgic confession the purpose can be indicated as "... [to] live a peaceful and quiet life in all piety and decency." Church order article 28, in relationship with article 36 of the Belgic confession does not call on believers to live in an ivory tower. To obey and honour the state government is after all not something that can be obtained through declarations by a church or church executive. It is something that should live in the hearts of the church (believers). Therefore the ministry of the gospel, the resuscitation of the believers to obey and honour state government is central to the confession and church order.

It is also the responsibility of the offices "... to arouse and retain the goodwill of the civil authorities towards the churches in the best interest of the churches." Article 28 also states that "... Church assemblies must communicate with the government in order to acquire the necessary cooperation from the government and, as the church of Christ, must bear testimony to the government in cases where the need to do so occurs." The point is that all church assemblies have the responsibility to correspond with state authorities on the level that is applicable. This should be viewed in correspondence with Article 30 of the church order. Article 30 states that "Church assemblies shall deal only with ecclesiastical matters and shall do so in an ecclesiastical manner. Major assemblies shall deal only with matters that cannot be finalized in minor assemblies or that concern all the churches in question collectively."

The Synod of 1970 (1970:63) decided that in the proclamation of the gospel the church ought to speak with courage and relevance about the issues presented in context of the day. By proclaiming the gospel the church should build up the believers, if necessary admonish them and if it is necessary criticize the actions and policy of the authorities and civil organizations. This approach is not without problems. The result may be that the churches are subdued to unbound subjectivism. It calls for a self-critical objectivism. Every issue should be adjudicated on its merits. The light of the Word should shine all aspects of life. In this way the church can be involved in all social issues, but then in an orderly church fashion (Van Wyk, 1991:344).

Vorster (1999:51) states that when the civil authorities govern in such a way that it promotes the basic values of Christian ethics the church Council (and churches in assembly) should impress upon the believers their responsibility to subject themselves to this authority; to establish and develop the goodwill of the authorities towards the church and seek their support for the work of the church; up correspondence with the civil authorities to gain the necessary support of the government in cases where this support is necessary; and bear testimony towards the government about the relevance of Biblical principles for social life. Vorster also states that the Bible and the confession do not expect blind and uncritical obedience from the believer towards the civil authority. He states that the civil authority should be obeyed and respected in all things: "which are not repugnant to the Word of God."

But what should be the preferred way for the churches if state government expresses itself hostile to the church, even reveal it as an enemy of the kingdom of God. Vorster (1999:51) suggests that in some circumstances obedience to the government may become difficult. $\mathrm{He}$ is of the opinion that in extreme cases civil disobedience or the violent overthrow of 
the government may be justified. The suggestion is in line with the established view in the reformed tradition which in extreme cases allows for violence to obtain the goal of better governance. It is mainly based on John Calvin's exposition of Daniel 6:22 and Acts 5:29 (cf. Inst. IV.20.32).

Van Wyk (1991:71), however, indicated that Calvin's view is not based on sound exegesis. In both instances of superior obedience to God (Daniel 6:22 and Acts 5:29) there is no indication of violent action against the authorities. It is also clear that Calvin does not apply his mind to the way and method according which violent action against the authorities may be executed. Furthermore, religion and politics do not fulfil a determinative function in the mentioned passages. I agree with the conclusion of Van Wyk that there is no genuine alternative for peaceful resistance.

\section{Remarks}

In summary it could be stated that the Reformed Churches in South Africa have a positive attitude towards the state as a servant of God. Preferably church and state should be able to work together regarding issues of mutual interest. The precondition is that the separation of church and state may not be compromised. For the churches it is about freedom in the state, to exercise their mandate according sound Scriptural conduct. Therefore the freedom of the church in the state cannot be viewed without emphasis on the responsibility of the churches in context of state legislation.

For the church, however, it means the exercise of their mandate without compromising the basic principles of justice and equity. Just is just in church and state. The way it is exercised may differ in church and state because of the difference in foundation, nature and focus. But it is my belief that in most instances church and state is not, at least in theory that far apart in the execution of justice and equity. It is not necessary for the church to develop a formidable internal law based on the common law. As a religious community the church should act in terms of the basic principles of Scriptures. For example, what is the implication of the Scriptural principle that a believer should act against other people as you wish for them to act towards you in terms of the execution of church discipline. It is the responsibility of the church to develop its internal practices based on these principles of Scriptures to be able to execute its mandate.

\section{BibLIOGRAPHY}

BELGIC CONFESSION. (In Die Berymde Psalms. 1992. Kaapstad: NG Kerk Uitgewers.)

CALVIN, J. 1998. Commentary on the Prophet Daniel. Ages Digital Library: The John Calvin Collection.

CALVIN, J. 1998. Institutes of the Christian Religion. Ages Digital Library: The John Calvin Collection.

CHURCH ORDER OF THE REFORMED CHURCHES IN SOUTH AFRICA. 1998. Potchefstroom: Admin. Buru van die GKSA.

COETZEE, C.F.C. 2006. Godsdiensvryheid in die lig van artikel 36 NGB. Nederduitse Gereformeerde Teologiese Tydskrif, 47 (1\&2): 143-157.

DAGBOEK VAN DIRK POSTMA. 2008. Vertaal deur Wim Vergeer en Janet du Plooy. Pretoria: V \& N Drukkery.

DU PLOOY, A. LE R. 1982. Kerkverband.'n Gereformeerd Kerkregtelike studie. Potchefstroom: PU vir CHO. (ThD-proefskrif).

DU PLOOY, A. LE R. 2008. Kerkorde en Grondwet - in die lig van die koninkryk. Nederduitse Gereformeerde Teologiese Tydskrif, 49 (1\&2): 243-252. 
GILIOMEE, H. 2003. The Afrikaners. Biography of a People. Cape Town: Tafelberg.

HANDELINGE VAN DIE SINODE. 1970. Handelinge van die sewe-en-dertigste sinodale vergadering van die Gereformeerde Kerke in Suid-Afrika. Potchefstroom:

Potchefstroom Herald.

HANDELINGE VAN DIE SINODE. 1982. Handelinge van die een-en-veertigste sinode van die Gereformeerde Kerke in Suid-Afrika. Potchefstroom: Potchefstroom Herald.

JANSEN, Joh. 1952. Korte verklaring van de Kerkorde. Kampen: Kok.

JOOSTE, J.P. 1958. Die geskiedenis van die Gereformeerde Kerk in Suid-Afrika. 1859-1959.

MULLER, D.F. 2010. Die roeping van Suid-Afrikaanse owerhede binne'n grondwetlike demokrasie in die lig van artikel 36 van die Nedelandse Geloofsbelydenis. (Proefskrif, Noordwes Universiteit, Potchefstroom Kampus).

SCHOLTZ, G.D. 1956. Die Geskiedenis van die Nederduitse Hervormde of Gereformeerde Kerk van SuidAfrika. 1842-1885. Pretoria: N.G. Kerk-uitgewers.

SMIT, C.J. 1997. A governing of the heart. Mainly as seen by John Calvin. (In Neuser, W. \& Selderhuis, H.J. red. Leiden: Groen en Zoon.)

SMIT, J. 2009. Grense tussen kerk en staat vir die reëling van die predikantsdiens:

gesien vanuit twee kerkregtelike tradisies. In die Skriflig, 43 (3): 473-496.

SPOELSTRA, B. 1963. Die Doppers in Suid-Afrika. 1760-1899. Pretoria: Nasionale

Boekhandel.

SPOELSTRA, C. 1915. Het Kerklijk en Godsdienstig leven der Boeren na den Grooten Trek. Kampen: J.H. Kok.

THEON, J. \& DE WIT, J. 2010. The relationship between the state and the church during the early history of Pretoria. Studia Historiae Ecclesiasticae, 36 (2): 147-166.

VAN WYK, J.H. 1991. Deo magis. Oor gehoorsaamheid aan God en (on)gehoorsaamheid aan die owerheid. (In VAN WYK, J.H. Moraliteit en verantwoordelikheid. Potchefstroom: PU vir CHO.) 109-127.

VAN WYK, J.H. 1991. Besinning oor die twee ryke-leer. (In VAN WYK, J.H. Moraliteit en verantwoordelikheid. Potchefstroom: PU vir CHO.) 213-244.

VORSTER, J.M. 1999. An introduction to Reformed Church Polity. Potchefstroom: Potchefstroomse Teologiese Publikasies.

email: johannes.smit@nwu.ac.za 